\title{
RAGAM PEMAHAMAN MAHASISWA PADA PEMBELAJARAN BAHASA ARAB
}

\author{
Dian Ekawati \\ Institut Agama Islam Negeri (IAIN) Metro \\ Jl. Ki Hajar Dewantara, Iringmulyo, Metro Timur, \\ Kota Metro, Lampung 34112 \\ email:azfadm01@gmail.com
}

\begin{abstract}
Abstrak
Dalam sejarah pendidikan Islam, pendidikan bahasa Arab di Indonesia dimulai dari lembaga pendidikan non formal atau pondok pesantren. Perkembangan bahasa Arab semakin nampak dengan dimasukkanya pelajaran bahasa Arab dalam mata pelajaran formal di sekolah-sekolah agama. PGMI adalah salah satu jurusan di Fakultas Tarbiyah Ilmu Keguruan IAIN Metro yang mencetak alumni siap terjun menjadi tenaga pendidik di tingkat Madrasah Ibtidaiyah. Kenyataan yang ditemui bahwa tidak semua mahasiswa PGMI berasal dari lulusan sekolah berbasis agama atau pernah tinggal di pesantren. Sebagian besar mereka merupakan alumni sekolah umum, dan belum mendapatkan materi bahasa Arab di sekolahnya. Mata kuliah bahasa Arab merupakan salah satu mata kuliah wajib di IAIN Metro. Pra survey pada jurusan PGMI diperoleh data bahwa mahasiswa mendapatkan nilai bahasa Arab rata-rata kelas yaitu 70, sedangkan yang mendapatkan nilai 85 hanya 6,8\% nya dari total jumlah mahasiswa PGMI semester II sejumlah 104 orang. Yang mendapatkan nilai 60 ada 3 orang dan nilai gagal yaitu 1 orang. Adapun Jenis penelitian ini yaitu penelitian deskriptif-kualitatif. Dengan hasil akhir penelitian adalah; mahasiswa yang sudah mempelajari bahasa Arab pada sekolah berbasis agama sebelumnya tidak akan mendapatkan banyak kesulitan dalam mengikuti perkuliahan mata kuliah bahasa Arab di jurusan PGMI. Sementara mahasiswa yang belum pernah mempelajari bahasa Arab di bangku sekolah menemui kesulitan dalam mempelajari bahasa Arab.
\end{abstract}

Kata Kunci: Ragam Pemahaman, Bahasa Arab, Mahasiswa. 


\section{A. Pendahuluan}

Bahasa adalah alat komunikasi yang digunakan manusia dalam menyampaikan ide, gagasan, pemikiran, keinginan, hasrat, kemauan dan sesuatu yang terpendam dalam hati manusia kepada sesama manusia. Bahasa merupakan alat yang sangat tepat digunakan manusia untuk bersosialisasi antar sesamanya baik di lingkungan keluarga, sekolah maupun masyarakat. Dengan bahasa, manusia akan bisa mengerti tentang ilmu pengetahuan dari berbagai aspek dan bidang.

Setiap negara mempunyai bahasa resmi nasional yang digunakan sebagai bahasa persatuan. Warga antar negara juga menggunakan bahasa Internasional untuk berkomunikasi dengan warga negara lainnya. Dewasa ini, masyarakat dunia menggunakan beberapa bahasa sebagai alat komunikasi dalam taraf Internasional. Diantaranya ialah bahasa Inggris, bahasa Perancis dan bahasa Arab.

Bahasa Arab sebagai bahasa agama, dikenal oleh seluruh umat Islam. Kedudukan agama menjamin keberadaannya (bahasa Arab) di tengah-tengah masyarakat selama ia masih dipeluknya. Sehingga dengan demikian nampaklah erat kaitan antara bahasa Arab dengan agama, yang tercermin dalam keberadaan al-Qur'an itu sendiri. Sedang keberadaan al-Quran dan kelestarian hukum-hukumnya dijaga oleh Allah S.W.T. ${ }^{1}$

Dalam sejarah pendidikan Islam, pengenalan pendidikan bahasa Arab di Indonesia dimulai dari lembaga pendidikan non formal atau pondok pesantren. Peserta didik yang belajar disana dinamakan dengan santri. Sedangkan pendidik yang mengajar di sana lazim dipanggil dengan ustadz dan ustadzah.

Pendidik berasal dari kata didik yang berarti cara-cara mendidik atau memelihara dan memberi latihan. ${ }^{2}$ Seiring berjalannya waktu, perkembangan bahasa Arab semakin berkembang pesat. Sehingga pemerintah membuat kebijakan untuk memasukkan pembelajaran bahasa Arab dalam suatu pendidikan formal yang terangkum dalam pendidikan agama Islam yang diberikan pada sekolah agama atau madrasah.

Setelah sekian waktu bahasa Arab menjadi pelajaran yang masuk dalam pelajaran Pendidikan Agama Islam, pada akhirnya pelajaran bahasa Arab diatur dalam kurikulum sebagai pelajaran sendiri. Dengan berbagai keterampilan berbahasa yang ada di dalamnya. Maka terbentuklah kurikulum yang mencantumkan bahasa Arab sebagai mata pelajaran wajib di sekolahsekolah Agama, baik dari sekolah dasar yang dinamakan dengan MI

1 Abdul Mu'in, Analisis Kontrastif Bahasa Arab dan Bahasa Indonesia: Telaah terhadap Fonetik dan Morfologi (Jakarta: Pustaka Al Husna Baru, 2004), h. 24.

${ }^{2}$ Ridjaluddin F. N. dan Anang Rohwiyono, Bunga Rampai Pendidikan Islam (Jakarta: Pusat Kajian Islam FAI UHAMKA, 2008), h. 148. 
(Madrasah Ibtidaiyah), MTs (Madrasah Tsanawiyah), maupun MA (Madrasah Aliyah) dibawah naungan Departemen Agama atau yang saat ini menjadi Kementerian Agama.

Bahasa Arab tak ubahnya bahasa-bahasa lain di dunia. Ia tumbuh dan berkembang sesuai kepentingan orang-orang yang menggunakannya. Suatu bahasa hidup atau mati sangat ditentukan oleh sejauh mana masyarakat memakainya dalam berbagai aspek kehidupan mereka. Suatu bahasa dikatakan hidup jika masyarakat masih memakainya dalam kehidupan seharihari, dan dikatakan mati jika dikatakan sebaliknya. ${ }^{3}$

Di Provinsi Lampung, bahasa Arab juga telah diterapkan dalam beberapa perguruan tinggi Islam. Seperti UIN (Universitas Islam Negeri), IAIN (Institut Agama Islam Negeri). Sebagai perguruan tinggi agama Islam, maka kedua perguruan tinggi tersebut menjadikan mata kuliah bahasa Arab sebagai mata kuliah wajib yang harus diikuti oleh semua mahasiswa dari berbagai jurusan.

Pemberian mata kuliah bahasa Arab di setiap jurusan bertujuan agar seluruh alumni dari perguruan tinggi tersebut mengenal dan mengerti akan bahasa Arab. Karena tidak bisa dipungkiri, dengan mempelajari bahasa Arab akan membantu mahasiswa (yang seluruhnya muslim) dalam mempelajari AlQur'an dan Hadits sebagai pedoman dalam melaksanakan kehidupannya sebagai hamba Allah dalam bermasyarakat.

Pendidikan Islam adalah pendidikan manusia seutuhnya, akal dan hatinya, rohani dan jasmaninya, akhlak dan keterampilannya, karena pendidikan Islam menyiapkan manusia untuk hidup, baik dalam damai ataupun perang. Dan menyiapkan untuk menghadapi masyarakat dengan segala kebaikan dan kejahatannya, manis dan pahitnya. ${ }^{4}$

Di Institut Agama Islam Negeri (IAIN) Metro, Mata kuliah bahasa Arab diberikan di semua jurusan yang ada. Salah satunya adalah jurusan PGMI (Pendidikan Guru Madrasah Ibtidaiyah). PGMI merupakan salah satu jurusan di Fakultas Tarbiyah dan Ilmu Keguruan yang mencetak alumnialumni yang siap terjun menjadi tenaga pendidik di tingkat sekolah dasar atau madrasah ibtidaiyah. Alumni PGMI nantinya diharapkan akan mampu bersaing di masyarakat untuk menerapkan ilmu yang pernah diperolehnya selama di bangku perkuliahan. Salah satu mata kuliah yang wajib diambil oleh mahasiswa jurusan PGMI yaitu Bahasa Arab I dan Bahasa Arab II.

Berdasarkan observasi, penulis menemui kenyataan bahwa dalam proses pembelajaran bahasa Arab sangat diperlukan pengetahuan dasar bahasa Arab dari mahasiswa demi kelancaran mereka dalam mengikuti pembelajaran

\footnotetext{
${ }^{3}$ Mu'in, Analisis Kontrastif Bahasa Arab dan Bahasa Indonesia: Telaah terhadap Fonetik dan Morfologi, h. 24.

${ }^{4}$ Ridjaluddin F. N. dan Rohwiyono, Bunga Rampai Pendidikan Islam, h. 149.
} 
bahasa Arab selanjutnya di bangku perkuliahan. Pengetahuan itu tentunya mereka dapatkan di sekolah-sekolah mereka sebelumnya.

Namun pada kenyataanya, tidak semua mahasiswa PGMI berasal dari lulusan sekolah yang berbasis agama atau pernah tinggal di pesantren, yang menerapkan pembelajaran bahasa Arab dalam pendidikan formal maupun program intensifikasi bahasa Arab di luar kelas. Sebagian besar mereka berasal dari sekolah umum, dan sama sekali belum mendapatkan pelajaran bahasa Arab di kelasnya. Bahkan mereka memang belum tahu tentang bahasa Arab, karena mereka belum pernah mendapatkan pelajaran bahasa Arab dari SD hingga SMA. Sehingga mata kuliah bahasa Arab yang mereka ambil di kampus menjadi pengalaman baru bagi mereka.

Misalnya mengenal tentang mufradat Arab, mempelajari bagaimana tata gramatika bahasa Arab dalam pembelajaran nahwu dan sharaf. Melatih pendengaran dan menguji kemampuan mengingat setiap kalimat dalam pembelajaran istima', belajar membaca teks-teks Arab dengan tepat (qiro'ah), dan belajar menulis Arab dengan benar (kitabah). Itu semua menjadi hal baru yang membuat mereka harus lebih serius dalam belajar bahasa Arab.

Mata kuliah bahasa Arab adalah bidang ilmu yang harus dipelajari secara kontinuitas terus menerus dan berkelanjutan. Memerlukan waktu yang lama untuk bisa secara sempurna memahami bidang ilmu ini. Jika dalam bahasa Inggris mempelajarinya hanya dengan cukup bisa dalam membaca tulisan yang berbeda dengan ucapan dan menulis kalimat disesuaikan dengan tensesnya, namun mempelajari bahasa Arab lebih rumit.

Dalam pembelajaran bahasa Arab, harakat yang ada di setiap kalimat tidak secara asal saja diberikan. Ketentuan harakat fathah, dhammah dan kasrah ada aturan tersendiri sesuai dengan kedudukan dari masing kata yang tersusun dalam sebuah kalimat berbahasa Arab/ I'rab. I'rab adalah perubahan akhir kalimah yang disebabkan oleh adanya 'amil yang terdapat pada kalimah itu, baik 'amil jazim. ${ }^{5}$ Pemberian harakat akhir di setiap kalimat juga ditentukan ketepatannya dalam ilmu sharaf. Itulah yang membuat mahasiswa PGMI lulusan sekolah umum kesulitan dalam mempelajarinya.

Hal tersebut merupakan pengalaman pertama bagi mereka mengenal bahasa Arab dengan berbagai ragam pengetahuan yang ada di dalamnya. Tentu masih banyak lainnya yang semuanya menjadi hal baru bagi mereka. Ini tentu saja menjadi kendala yang sangat berarti dalam pelaksanaan perkuliahan bahasa Arab. Dimana pengelompokkan mahasiswa dalam satu kelas bukan berdasarkan tingkat pemahaman yang sama tentang bahasa Arab. Hanya sebagian saja dari mahasiswa tersebut yang memiliki pengetahuan

5 Imaduddin Sukamto dan Akhmad Munawari, Tata Bahasa Arab Sistematis: Pendekatan Baru Mempelajari Tata Bahasa Arab (Yogyakarta: Nurma Media Idea, 2007), h. 50. 
dasar tentang bahasa Arab. Karena sebagian dari mereka berasal dari sekolah berbasis agama atau pernah belajar di pondok pesantren, dan ada juga yang sedang belajar di pondok pesantren. Sehingga mereka mendapatkan pengetahuan tentang bahasa Arab secara berkelanjutan di pesantrennya. Pengetahuan bahasa Arab yang mereka dapatkan membuat mereka lebih mudah mempelajari bahasa Arab di Jurusan PGMI.

Peneliti melakukan wawancara dengan dosen yang mengajar bahasa Arab di jurusan PGMI semester II tentang prestasi mahasiswa PGMI dalam belajar bahasa Arab. Wawancara dilakukan pada hari kamis tanggal $31 \mathrm{Mei}$ 2019. Setelah selesai diadakan ujian semester pembelajaran bahasa Arab PGMI semester II dan peneliti dapatkan data sebagai berikut:

a. Mahasiswa yang mendapatkan nilai rata 80 sebanyak 15 orang,

b. Mahasiswa yang mendapatkan nilai rata-rata 70 sebanyak 85 orang

c. Mahasiswa yang mendapatkan nilai rata-rata 60 sebanyak 3 orang.

d. Mahasiswa yang mendapatkan nilai rata-rata 0 atau E sebanyak 1 orang. ${ }^{6}$

Dari data nilai di atas terlihat bahwa ada perbedaan perolehan prestasi belajar bahasa Arab mahasiswa PGMI dari lulusan sekolah berbasis agama dan umum. Mahasiswa rata-rata mendapatkan nilai bahasa Arab 70 sedangkan yang mendapatkan nilai 85 hanya $6,8 \%$ nya atau 15 orang saja dari total jumlah mahasiswa PGMI semester II sejumlah 104 orang. Yang mendapatkan nilai 60 ada 3 orang dan nilai gagal 1 orang.

Hal tersebut menunjukkan bahwa kemampuan rata-rata mahasiswa PGMI semester II dalam kegiatan pembelajaran bahasa Arab yang bisa peneliti simpulkan ialah masih mencapai tahap kemampuan standar rata-rata. Dan perlu dianalisa lebih lanjut tentang proses pembelajaran mereka untuk mencari tahu adakah kendala yang menjadi penghambat kelancaran proses pembelajaran mahasiswa PGMI tersebut.

Berdasarkan fenomena tersebut, maka penulis ingin untuk mengetahui bagaimanakah ragam pemahaman mahasiswa PGMI semester II Tahun Akademik 2017-2018 pada proses pembelajaran bahasa Arab. Dan kemudian menganalisa sejauh mana tingkat kesulitan mereka yang berasal dari lulusan sekolah berbasis agama ataupun umum, apakah mereka pernah atau sedang mengenyam pendidikan di pondok pesantren ataukah tidak.

Adapun penelitian ini bertujuan untuk mengetahui ragam pemahaman bahasa Arab dan tingkat kesulitan, serta menganalisis pemahaman mahasiswa PGMI tahun akademik 2017-2018 yang berasal dari lulusan sekolah berbasis agama ataupun pondok pesantren.

${ }^{6}$ Hasil wawancara Peneliti dengan Dosen Pengampu mata kuliah Bahasa Arab 2 PGMI Semester II Tahun Akademik 2017-2018 


\section{B. Kerangka Teori}

1. Ragam Pemahaman

Beragam yaitu banyak ragamnya; bermacam-macam; berwarnawarni; ramai. ${ }^{7}$ Ragam adalah menunjukkan sesuatu yang beragam, baik itu dari corak, macam, dan pemahaman. Dalam penelitian ini yang dimaksud ragam adalah macam tingkat pemahaman bahasa Arab mahasiswa karena perbedaan asal sekolah sebelumnya. Sedangkan pemahaman berarti proses, cara, perbuatan memahami atau memahamkan. ${ }^{8}$

Jadi, yang dimaksud ragam pemahaman bahasa Arab adalah bermacam-macam pemahaman, pengetahuan, pendapat tentang bahasa Arab. Sedangkan ragam tingkat pemahaman bahasa Arab adalah bermacam tingkat pemahaman bahasa Arab yang dimiliki oleh peserta didik dalam proses pembelajaran. Tingkatan disini yang dimaksud adalah pemahaman yang sudah sangat mengerti, yang sedang mengerti, yang hanya secara dasar mengerti, dan belum mengerti.

Merujuk pada judul tentang keragaman mahasiswa PGMI lulusan sekolah berbasis agama dan umum dalam pembelajaran bahasa Arab diartikan bahwa tingkatan pemahaman yang dimiliki oleh mahasiswa lulusan sekolah umum tentang bahasa Arab dan tingkatan pemahaman mahasiswa PGMI lulusan sekolah berbasis agama tentang bahasa Arab. Hal ini menarik karena fenomena di lapangan terlihat bahwa kurikulum sekolah umum tidak tercantum mata pelajaran bahasa Arab. Itu berarti bahwa pelajaran bahasa Arab belum dipelajari oleh peserta didik yang duduk di bangku SMA.

\section{Pembelajaran Bahasa Arab}

\section{a. Pengertian Pembelajaran}

Belajar adalah kegiatan yang secara sengaja dilakukan oleh individu dalam hal ini peserta didik untuk melakukan proses kegiatan yang sengaja dilakukan dengan tujuan untuk memperoleh pengetahuan baru pengalaman baru atau memperbaiki pengetahuan yang belum tepat. Maka pembelajaran adalah proses interaksi peserta didik dengan pendidik dan sumber belajar pada suatu lingkungan belajar. ${ }^{9}$ Belajar adalah terjadinya interaksi dalam proses pentransferan informasi pendidik kepada peserta didik. Belajar juga bisa dipahami sebagai proses individu/

7 "Arti Kata Ragam," Kamus Besar Bahasa Indonesia (KBBI) Online, diakses 9 Oktober 2019, https://kbbi.web.id/ragam.

8 "Arti Kata Paham," Kamus Besar Bahasa Indonesia (KBBI) Online, diakses 10 Oktober 2019, https://kbbi.web.id/paham.

${ }^{9}$ M. Khalilullah, Media Pembelajaran Bahasa Arab (Yogyakarta: Aswaja Pressindo, 2012), h. 3. 
anak didik untuk mendapatkan pemahaman yang lebih jelas tentang pengetahuan yang telah dimilikinya.

Misalnya seorang mahasiswa PGMI telah mempelajari mata kuliah bahasa Arab I di semester I, tapi kemudian ia mempelajari kembali bahasa Arab II di semester II. Hal itu bertujuan agar pemahaman mahasiswa tersebut menjadi semakin bertambah. Sehingga kebingungan yang mungkin dirasakannya tentang bahasa Arab di semester I bisa dihilangkan di semester II. Belajar akan dirasa berhasil jika apa yang dipelajarinya sudah bisa dipahami oleh seorang individu. Dan belajar dirasa kurang berhasil jika apa yang dipelajarinya masih menyimpan kebingungan dan pertanyaan-pertanyaan yang belum terjawab.

Belajar adalah suatu proses yang dilakukan individu untuk memperoleh suatu perubahan tingkah laku yang baru secara keseluruhan, sebagai pengalaman individu itu sendiri dalam interaksi dengan lingkungannya. ${ }^{10}$ Sehingga dapatlah disimpulkan bahwa pembelajaran adalah bantuan yang diberikan oleh pendidik kepada peserta didik untuk memperoleh pengetahuan, pembentukan sikap, akhlak, perilaku yang lebih baik dengan sengaja dilakukan di suatu lingkungan belajar.

Mengajar yaitu proses penyampaian informasi atau pengetahuan dari guru kepada siswa. ${ }^{11}$ Mengajar memiliki pengertian dari sudut yang berbeda, yaitu secara kuantitatif, kualitatif dan institutional. Secara kuantitatif, mengajar berarti the transmission of knowledge, yaitu pemindahan pengetahuan. Secara kualitatif, mengajar diartikan sebagai the facilitation of learning, yakni upaya membantu memudahkan kegiatan belajar siswa. Dalam hal ini, guru berperan memfasilitasi siswa untuk aktif belajar dan menciptakan kondisi yang mendukung terciptanya kegiatan belajar mengajar siswa. Sementara secara institusional, mengajar berarti the efficient orchestration of teaching skills, yakni penataan segala kemampuan mengajar secara efisien. ${ }^{12}$

Dari pendapat di atas bisa dipahami bahwa mengajar adalah proses mentransfer atau memfasilitasi siswa dalam kegiatan pembelajaran. Mengajar adalah usaha membantu memudahkan siswa dalam memahami pengetahuan. Mengajar bahasa Arab adalah upaya pemberian pengetahuan tentang bahasa Arab kepada peserta didik serta berperan sebagai fasilitator dalam menciptakan suasana pembelajaran bahasa Arab yang baik.

\footnotetext{
${ }^{10}$ Aunurrahman, Belajar dan Pembelajaran (Bandung: Alfabeta, 2009), h. 34.

${ }^{11}$ Wina Sanjaya, Strategi Pembelajaran (Jakarta: Kencana Prenada Media Group, 2006), h. 95.

12 Jamil Suprihatiningrum, Strategi Pembelajaran Teori dan Aplikasi (Yogyakarta: ArRuzz Media, 2013), h. 60-61.
} 


\section{b. Pengertian Bahasa Arab}

Bahasa adalah alat komunikasi, alat penyampai pesan, alat interaksi antar sesama manusia. Bahasa sangat diperlukan dalam berbagai aktivitas di dunia. Bahasa adalah alat yang digunakan untuk mendeskripsikan ide, pikiran, atau tujuan melalui struktur kalimat yang dapat dihamai orang lain. ${ }^{13}$ Bahasa Arab sendiri adalah bahasa Internasional yang digunakan oleh masyarakat dunia dalam berkomunikasi dan berinteraksi. Bahasa Arab senantiasa menghiasi kehidupan umat muslim dalam setiap ibadahnya.

Bahasa Arab merupakan bahasa Al-Qur'an dan menjadi salah satu alat komunikasi internasional. Oleh karena itu mempelajari bahasa Arab menjadi kebutuhan setiap orang khususnya umat Islam. ${ }^{14}$ Namun dengan begitu, bahasa Arab bukanlah bahasa milik muslim. Bahasa Arab adalah milik seluruh manusia di bumi ini. Karena bahasa Arab digunakan bukan hanya oleh muslim tapi juga oleh non muslim. Dan tidak semua muslim menggunakan bahasa Arab dalam komunikasinya sehari-hari.

Hubungan politik dan ekonomi yang ingin dijalin antara negaranegara non Arab dengan negara-negara Arab membuat mereka sangat antusias ingin mempelajari bahasa Arab. Hal itulah yang menyebabkan bahasa Arab menjadi sangat terkenal di mata masyarakat internasional. Bahasa Arab masih merupakan bahasa yang tetap bertahan keInternasionalannya, sejajar dengan bahasa Internasional modern yakni bahasa Inggris dan Perancis. ${ }^{15}$ Kedudukan istimewa yang dimiliki bahasa Arab di antara bahasa-bahasa lain di dunia karena ia berfungsi sebagai bahasa al-Qur'an dan Hadits serta kitab-kitab lainnya. ${ }^{16}$

Di Indonesia sendiri, pengenalan tentang bahasa Arab telah dilaksanakan lewat sekolah-sekolah agama atau madrasah baik dari tingkat MI, MTs dan MA. Sehingga siswa yang merupakan lulusan dari madrasah tersebut sudah pernah mempelajari tentang bahasa Arab. Sementara sekolah umum di Indonesia saat ini, ada yang sudah mulai mengenalkan bahasa Arab. Namun hanya sebatas bahasa pilihan dan hanya dengan waktu yang terbatas. Bahkan ada yang belum mengenalkan bahasa Arab sama sekali. Sehingga lulusan dari sekolah umum, ada yang sudah mengenal bahasa Arab walau hanya sebatas pengetahuan dasarnya saja dan ada yang sama sekali belum mengenal bahasa Arab.

13 Acep Hermawan, Metodologi Pembelajaran Bahasa Arab (Bandung: Remaja Rosdakarya, 2014), h. 8.

14 Sukamto dan Munawari, Tata Bahasa Arab Sistematis: Pendekatan Baru Mempelajari Tata Bahasa Arab, h. 7.

${ }^{15}$ Azhar Arsyad, Bahasa Arab dan Metode Pengajarannya (Yogyakarta: Pustaka Belajar, 2003), h. 10.

${ }^{16}$ Arsyad, h. 7. 


\section{c. Pembelajaran bahasa Arab}

Bahasa Arab terdiri dari beberapa cabang ilmu antara lain: Nahwu, Saraf, Balaghah, Mutholaah, Mufradat, Nushus Adab, dan lain-lain. Suatu sistem pembelajaran bahasa Arab yang ideal disamping mampu mengantarkan siswa menguasai cabang-cabang ilmu tersebut diatas, juga mampu mengantarkan siswa mempunyai keterampilan-keterampilan bahasa (مهارة اللغة). Keterampilan-keterampilan itu antara lain: Keterampilan mendengarkan (مهارة الإسنماع), Keterampilan berbicara (مهارة الكلام), Keterampilan membaca (مهارة القراءة), Keterampilan menulis (مهارة الكتابة)

Dalam mempelajari satu keterampilan saja, sebetulnya peserta didik harus mempelajarinya dalam waktu yang relatif tidak singkat. Sehingga untuk memahami keseluruhan keterampilan tersebut, maka peserta didik seharusnya mempunyai bekal pengetahuan sebelumnya supaya proses pembelajaran berjalan lebih maksimal dan efektif. Seandainya ada siswa yang pandai berbahasa Arab di sekolah atau perguruan tinggi, tentu kepandaiannya itu tidak berasal dari sekolah, akan tetapi dari lembaga tinggi lainnya seperti ma'had (ponpes) atau dari lingkungan keluarganya sendiri. ${ }^{18}$

Untuk menguasai bahasa Arab dengan baik semua maharah/ skill yang terkandung dalam bahasa Arab, sebaiknya individu mendapatkan pembelajaran bahasa Arab dari tingkat dasar pula. Namun kenyataanya, tidak semua individu mendapatkan kesempatan yang sama dalam belajar bahasa Arab. Banyak dari individu yang tidak mendapatkan pembelajaran bahasa Arab dari tingkat dasar hingga pendidikan menengah atas jika yang ia lalui adalah jenjang pendidikan umum semua. Sekolah dasar negeri dan sekolah menengah pertama negeri memang belum memasukkan mata pelajaran bahasa Arab dalam kurikulum formalnya.

Sementara sekolah menengah atas negeri ada yang sudah memasukkan mata pelajaran bahasa Arab di kurikulum formalnya tapi masih banyak yang belum memasukkan mata pelajaran bahasa Arab dalam kurikulum pembelajaranya. Inilah yang dialami oleh sebagian mahasiswa semester II PGMI IAIN Metro.

Belajar bahasa Arab berarti belajar keempat keterampilan yang dimiliki oleh bahasa Arab. Keterampilan itu ialah istima'(menyimak), kalam (berbicara), membaca (qiro'ah) dan menulis (kitabah). Keempat keterampilan tersebut sangat dipengaruhi oleh kemampuan penguasaan mufradat/ kosakata yang dimiliki si pebelajar.

17 Sukamto dan Munawari, Tata Bahasa Arab Sistematis: Pendekatan Baru Mempelajari Tata Bahasa Arab, h. 7.

${ }^{18}$ Suja'i, Inovasi Pembelajaran Bahasa Arab (Semarang: Walisongo Press, 2008), h. 2. 
Fenomena yang muncul bahwa peserta didik tidak semuanya memiliki bekal pengetahuan bahasa Arab di bangku Sekolah Menengah Atas akan menjadi catatan tersendiri dalam proses pelaksanaan pembelajaran bahasa Arab di Jurusan PGMI semester dua. Aspek linguistik dan aspek penguasaan kosakata adalah dua hal yang signifikan dalam mempelajari bahasa Arab.

Aspek linguistik menentukan kelancaran berbahasa seorang. Seberapa mampu mahasiswa bercakap-cakap dan berkomunikasi dengan bahasa Arab dengan benar dan baik. Sedangkan penguasaan kosakata sangat diperlukan dalam pembelajaran bahasa Arab. Penguasaan kosakata juga menjadi target tujuan pembelajaran bahasa Arab. Hendaknya penguasaan mufradat diwajibkan bagi setiap mahasiswa yang belajar bahasa Arab. Penguasaan mufradat beserta artinya menjadi hal yang diwajibkan oleh seorang dosen kepada mahasiswanya.

\section{d. Problematika Pembelajaran Bahasa Arab}

Pembelajaran bahasa Arab di Indonesia ialah pembelajaran bahasa Arab bagi non Arab. Karena obyek didiknya adalah anak didik yang bukan berkewarganegaraan Arab dan tidak menggunakan bahasa Arab dalam percakapan sehari-harinya baik di lingkungan sekolah maupun di luar sekolah.

Pembelajaran bahasa Arab bagi non Arab merupakan satu hal yang tidak bisa dihindari, Karena urgensi bahasa Arab bagi masyarakat dunia saat ini, cukup tinggi baik yang muslim maupun non muslim. Hal ini terbukti dengan banyaknya lembaga-lembaga pembelajaran bahasa Arab di berbagai negara antara lain Institut Kajian Keislaman di Madrid Spanyol, Institut Syamlan di Lebanon, markaz Khartoum di Sudan, LIPIA di jakarta, Institut-institut Pembelajaran Bahasa Arab milik Yayasan alKhoiry dari Emirat Arab di Indonesia. ${ }^{19}$

Pada dasarnya, pembelajaran bahasa asing tidaklah mudah, Dalam proses pembelajarannya akan terdapat kesulitan-kesulitan yang dihadapi oleh pendidik dan peserta didik. Sebagian dari kesulitan-kesulitan itu dikarenakan sebagian besar peserta didik masih menghafalkan kalimatkalimat (vocabularies) saja akan tetapi tidak mampu memahami maknanya.

Penguasaan kosakata tidak terbatas dengan jumlah. Semakin banyak kosakata maka semakin baiklah mahasiswa itu dalam memahami bahasa Arab. Banyaknya jumlah kosakata/mufradat yang dikuasai oleh mahasiswa akan memudahkan mereka dalam memahami kalimat-kalimat bahasa Arab, baik dalam bentuk jumlah ismiyah (الجملة الإسمية) atau kalimat

\footnotetext{
${ }^{19}$ Hermawan, Metodologi Pembelajaran Bahasa Arab, h. 99.
} 
nominal/ nominal sentence, maupun kalimat dalam bentuk jumlah fi'liyah atau kalimat verbal/ verbal sentence.

pengertiannya ialah kalimat yang didahului oleh kata benda, kemudian diikuti oleh kata benda atau kata kerja sebagai predikat, sedangkan الجملة الفعلية ialah kemudian diikuti oleh kata benda sebagai failnya/ pelaku kalimat yang didahului oleh kata kerja kemudian diikuti oleh kata benda sebagai failnya/ pelaku kalimat yang didahului oleh kata kerja. ${ }^{20}$

Pembagian kalimat dalam bahasa Arab pada dasarnya sama dengan pembagian kalimat dalam bahasa Indonesia atau Inggris, namun kelebihan bentuk kalimat dalam bahasa Arab adalah terletak dari harakat yang harus diberikan di setiap huruf-huruf Arab yang tersusun dalam sebuah kalimat. Ketepatan pemberian harakat akan sangat menentukan ketepatan arti yang dimaksudkan.

Kemampuan mahasiswa dalam belajar bahasa Arab secara baik dan benar adalah kemampuan mahasiswa dalam memahami ilmu nahwu dan shorofnya, karena pemberian harakat yang tepat dalam setiap kalimat dikaji dalam materi ilmu nahwu sedangkan ketepatan harakat akhir setiap kalimat dipelajari dalam ilmu sharaf. Kedua bidang ilmu ini hendaknya dipelajari mahasiswa secara benar agar hasil dari pemahaman mereka juga tepat sesuai yang diajarkan.

Hal lain yang merupakan problematika pembelajaran bahasa arab yaitu penerapan sistem nazhariyyah al wahdah. Kesimpulan penelitian oleh Novita Rahmi menyatakan bahwa alokasi waktu yang kurang memadai dan belum tersedianya laboratorium bahasa menjadi kendala umum pengajaran bahasa Arab. Dan untuk mengatasi permasalahan tersebut, setidaknya lembaga harus mempunyai minimal dua hal yaitu guru mata pelajaran bahasa Arab profesional dan lingkungan bahasa (bi'ah lughawiyah). ${ }^{21}$

\section{Indikator Pencapaian Keberhasilan Pembelajaran}

Indikator keragaman mahasiswa PGMI semester II dalam Pembelajaran bahasa Arab ialah: Kemampuan mahasiswa memahami dalam menguasai mufrodat bahasa Arab, kemampuan mahasiswa menyimak bacaan teks-teks Arab dengan baik, kemampuan mahasiswa membaca teks-teks Arab dengan tepat, kemampuan mahasiswa menuliskan kembali teks-teks Arab

20 Mawardi, Dasar-Dasar Pembelajaran Bahasa Arab (Sulawesi Selatan: Laskar Perubahan, 2015), h. 55.

${ }^{21}$ Novita Rahmi, "Problematika Penerapan Sistem Nazhariyyah Al Wahdah Pada Pembelajaran Bahasa Arab Di Madrasah Aliyah Se-Kota Metro Tahun 2018," An Nabighoh: Jurnal Pendidikan Dan Pembelajaran Bahasa Arab 21, no. 01 (2019): 61-76, https://doi.org/10.32332/an-nabighoh.v21i01.1253. 
yang didengarkan dengan tepat dan benar, kemampuan mahasiswa membuat beberapa kalimat berbahasa Arab.

Indikator kesulitan-kesulitan dalam Proses Pembelajaran bahasa Arab mahasiswa PGMI semester II ialah: Mahasiswa sangat sedikit sekali kesulitan dalam kegiatan Istima', mahasiswa sangat sedikit sekali tingkat kesulitan dalam memahami teks-teks Arab serta mahasiswa sedikit dalam memahami teks-teks Arab.

Beberapa indikator itu peneliti gunakan sebagai dasar peneliti untuk melakukan wawancara ke mahasiswa dalam rangka mendapatkan informasi mengenai hambatan atau kesulitan mereka dalam mempelajari bahasa Arab. Serta untuk peneliti jadikan dasar dalam menganalisa, langkah-langkah apa saja sebaiknya dilakukan oleh para dosen bahasa Arab di jurusan PGMI dalam menyampaikan materi kuliah bahasa Arab dengan tepat sasaran dan mencapai tujuan pembelajaran sesuai yang diharapkan.

Dengan mengetahui jumlah dari masing-masing lulusan dan asal sekolah mereka, peneliti akan bisa mempresentasikan manakah yang lebih banyak lulusan dari sekolah menengah umum atau agama. Hal ini berguna untuk mengetahui prosentase mahasiswa yang menguasai bahasa Arab atau yang belum menguasai bahasa Arab.

\section{Metodologi Penelitian}

Jenis penelitian Jenis penelitian ini adalah penelitian deskriptifkualitatif. Penelitian deskriptif adalah suatu penelitian yang analisis datanya hanya sampai pada deskripsi variabel satu demi satu. ${ }^{22}$ Penelitian kualitatif adalah penelitian yang bermaksud untuk memahami fenomena tentang apa yang dialami oleh subyek penelitian. Misalnya perilaku persepsi, motivasi, tindakan, pada suatu konteks khusus yang alamiah dan dengan memanfaatkan berbagai metode alamiah. ${ }^{23}$

Penelitian deskriptif adalah suatu metode penelitian yang ditujukan untuk menggambarkan fenomena-fenomena yang ada, yang berlangsung saat ini atau saat yang lampau. Penelitian ini tidak mengadakan manipulasi atau pengubahan pada variabel-variabel bebas, tetapi menggambarkan suatu kondisi apa adanya. ${ }^{24}$

Dalam Penelitian kualitatif adalah suatu penelitian yang datanya dinyatakan dalam bentuk verbal dan dianalisis tanpa menggunakan teknik

${ }^{22}$ Moh. Ainin, Metodologi Penelitian Bahasa Arab (Malang: Hilal Pustaka, 2007), h.

12.

${ }^{23}$ Lexy J. Moleong, Metodologi Penelitian Kualitatif (Bandung: Remaja Rosdakarya, 2012), h. 6.

${ }^{24}$ I'anatut Thoifah, Statistika Pendidikan dan Metode Penelitian Kuantitatif (Malang: Madani, 2006), h. 47. 
statistik. $^{25}$ Metodologi kualitatif sebagai prosedur penelitian yang menghasilkan data deskriptif berupa kata-kata tertulis atau lisan dari orangorang dan perilaku yang dapat diamati. ${ }^{26}$ Secara holistic dan dengan cara deskripsi dalam bentuk kata-kata dan bahasa. Metode dalam penelitian ini adalah metode komparatif yaitu penelitian yang diarahkan untuk mengetahui apakah antara dua variabel atau lebih dari dua kelompok ada perbedaan dalam aspek atau variabel yang diteliti. ${ }^{27}$

Merujuk pendapat di atas dalam penelitian ini penulis ingin mengetahui ragam pemahaman mahasiswa dan tingkat kesulitan yang dirasakan oleh mahasiswa yang berasal dari lulusan sekolah umum dan agama termasuk di dalamnya yang pernah atau sedang mukim di pondok pesantren dengan lulusan atau tidak pernah sama sekali mendapatkan pendidikan bahasa Arab di pondok pesantren dalam mempelajari bahasa Arab.

Lokasi Penelitian: Penelitian ini dilakukan di IAIN Metro Fakultas Tarbiyah dan Ilmu Keguruan (FTIK) Jurusan PGMI pada semester genap tahun akademik 2017-2018 dan semester ganjil tahun akademik 2018-2019.

Populasi merupakan wilayah generalisasi yang terdiri atas obyek dan subyek yang memiliki kualitas dan karakteristik tertentu yang ditetapkan oleh peneliti untuk dipelajari dan kemudian ditarik kesimpulannya. ${ }^{28}$ Populasi dan sampel dalam penelitian ini adalah seluruh mahasiswa PGMI IAIN Metro semester II tahun akademik 2017-2018.

Sumber data dalam penelitian ini adalah mahasiswa PGMI IAIN Metro pada semester genap tahun akademik 2017- 2018 dan dosen pengampu mata kuliah bahasa Arab di PGMI pada semester genap tahun 2017 dan buku- buku penunjang dalam proses penelitian.

Teknik pengumpulan data ialah wawancara untuk mendapatkan informasi tentang mahasiswa yang berasal dari lulusan sekolah agama dan umum serta yang pernah atau sedang menjadi santri di suatu pondok pesantren dan untuk mendapatkan data nilai mahasiswa PGMI dalam pembelajaran bahasa Arab serta metode dokumentasi untuk mendapatkan data dokumentasi proses wawancara peneliti dengan mahasiswa PGMI semester genap tahun ajaran 2017-2018.

\section{Pembahasan}

\section{Ragam Pemahaman Mahasiswa Pada Pembelajaran Bahasa Arab}

Berdasarkan hasil wawancara dengan ketiga kelas peneliti dapatkan informasi bahwa mahasiswa yang berasal dari lulusan sekolah berbasis agama telah mempelajari bahasa Arab di kelasnya. Sehingga mereka sudah mengenal

\footnotetext{
${ }^{25}$ Ainin, Metodologi Penelitian Bahasa Arab, h. 12.

${ }^{26}$ Moleong, Metodologi Penelitian Kualitatif, h. 4.

${ }^{27}$ Thoifah, Statistika Pendidikan dan Metode Penelitian Kuantitatif, h. 159.

${ }^{28}$ Sugiyono, Metodologi Penelitian Administrasi (Bandung: Alfabeta, 1999), h. 57.
} 
pelajaran bahasa arab dan mempelajari mata kuliah bahasa Arab. Jadi di jurusan PGMI merupakan kelanjutan proses belajar bahasa Arab dari kelas di level pendidikan sebelumnya.

Mahasiswa yang berasal dari lulusan pondok pesantren atau yang masih tinggal di pondok pesantren sudah mempelajari bahasa Arab. Mereka bahkan selalu mempelajari bahasa Arab baik secara formal belajar di kelas maupun informal belajar di luar jam pembelajaran. Bahkan bagi mereka yang tinggal di pondok pesantren modern diwajibkan untuk berkomunikasi dengan bahasa Arab dan bahasa Inggris dalam percakapan sehari-hari mereka di pesantren.

Mahasiswa yang berasal dari sekolah umum belum mempelajari bahasa Arab. Di Sekolah Menengah Atas Negeri belum diterapkan pembelajaran bahasa Arab sebagai pelajaran wajib. Kalaupun ada maka pelajaran bahasa Arab hanya masuk sebagai bahasa pilihan dari beberapa bahasa yang bisa dipilih oleh murid. Dan biasanya bahasa Arab lah yang mendapatkan peminat paling sedikit arena bahasa Arab dianggap bahasa yang tidak penting dipelajari dan kurang menarik.

Mahasiswa yang berasal dari Sekolah Menengah Kejuruan Negeri juga belum mempelajari bahasa Arab. Hal serupa juga dialami oleh mahasiswa yang berasal dari Sekolah Menengah Atas Negeri. Kedua sekolah ini hanya meletakkan bahasa Arab sebagai bahasa pilihan, dan pembelajaran akan dimulai jika calon peserta didik jumlahnya mencukupi. Tetapi jika jumlahnya tidak mencukupi, maka pembelajaran bahasa Arab tidak akan dimulai.

Berbeda dengan mahasiswa yang berasal dari Sekolah Menengah Kejuruan Swasta, mereka sudah ada yang mempelajari bahasa Arab. Sama halnya dengan Sekolah Menengah Atas Swasta yang biasanya dimiliki oleh organisasi keagamaan seperti Muhammadiyah dan NU. Karena SMK ini berada dibawah naungan yayasan organisasi agama Islam, maka pelajaran bahasa Arab dijadikan sebagai mata pelajaran wajib bagi seluruh siswa yang bersekolah di SMK ini. Hal ini membuat alumni lulusan dari sekolah menengah swasta mengetahui pelajaran bahasa Arab. Meskipun jam pelajarannya tidak sebanyak yang ada di Madrasah Aliyah. Namun setidaknya lulusan dari sekolah ini tahu akan pelajaran bahasa Arab.

Sementara mahasiswa yang berasal dari Madrasah Aliyah baik negeri atau swasta sudah mempelajari bahasa Arab karena mata pelajaran ini merupakan mata pelajaran yang masuk dalam kurikulum pendidikan di MA dan wajib dipelajari oleh seluruh siswanya. Bahkan jam pelajaran yang diterapkan di MA lebih banyak dibandingkan dengan Sekolah Menengah Kejuruan Swasta. Siswa alumni dari MA biasanya tidak akan mendapatkan banyak kesulitan dalam mempelajari bahasa Arab di pendidikan selanjutnya. Begitu juga dengan mahasiswa PGMI lulusan dari sekolah MA mereka tidak akan banyak menemui kesulitan dalam mempelajari bahasa Arab di kelasnya. 
Mereka sudah mempunyai bekal kosa kata yang sudah mereka hafal semenjak di bangku Madrasah aliyah.

Berbicara tentang mufradat memang menjadi hal yang sangat urgen yang menentukan kelancaran mahasiswa dalam mempelajari bahasa Arab. Semakin banyak perbendaharaan mufradat/kosakata Arab yang dimiliki mahasiswa maka semakin mudahlah mahasiswa memahami mata kuliah bahasa Arab. Dan sebaliknya semakin sedikit perbendaharaan kosakata yang dimiliki mahasiswa maka semakin sulit mereka mempelajari bahasa Arab.

Dari observasi tersebut bisa peneliti pahami pemahaman mahasiswa PGMI semester II memanglah beragam kemampuannya. Bahwa jika mahasiswi PGMI lulusan sekolah agama pernah mempelajari bahasa Arab di kelasnya sehingga mereka tidak mengalami kesulitan yang berarti dalam mempelajari bahasa Arab di bangku perkuliahannya. Mahasiswa yang pernah tinggal di pondok pesantren sudah mempelajari bahasa Arab dan tidak mengalami kendala dalam mempelajari bahasa Arab di bangku perkuliahan PGMI.

Mahasiswa yang berasal dari lulusan sekolah agama meski sudah pernah mempelajari bahasa Arab di kelasnya dan mereka tidak mengalami kendala yang berarti dalam belajar bahasa Arab di bangku perkuliahannya namun perbendaraan mufradat asing masih menjadi masalah bagi mereka karena belum pernah membaca sebelumnya.

Mufradat baru juga menjadi penyebab mahasiswa PGMI lulusan Madrasah Aliyah dan lulusan pondok pesantren tidak bisa memahami keseluruhan materi yang diberikan. Dalam mempelajari bahasa arab mahasiswa PGMI lulusan dari sekolah agama dan pondok pesantren memiliki sedikit kendala dalam mengartikan mufradat baru atau mufradat asing yang belum pernah dipelajari mereka sebelumnya. Tingkat kesulitan yang mereka peroleh hanyalah sebatas sedang sulit. Artinya mereka sudah tidak menemui kendala dalam mempelajari ilmu-ilmu dasar bahasa Arab.

Mahasiswa yang berasal dari sekolah umum baik SMU atau SMK negeri benar-benar belum mempelajari bahasa Arab. Sehingga tingkat kesulitan yang mereka miliki termasuk tingkat kesulitan pada level sangat sulit. Mereka hendaknya memulai pelajaran bahasa Arab dari penguasaan mufradat.

Hal ini menjadi bahan pertimbangan bagi dosen pengampu mata kuliah bahasa Arab dalam menyampaikan mata kuliahnya. Materi yang akan diberikan harus dikaji apakah sudah sesuai dengan tingkat pemahaman bahasa Arab mereka. Sementara kelas tidak dikelompokkan berdasarkan kesamaan kemampuan bahasa Arab mahasiswa tetapi berdasarkan penyusunan kartu rencana studi (KRS).

Jika materi ajar yang diberikan terlalu tinggi maka lulusan sekolah umum tidak akan bisa mengikuti proses pembelajaran. Namun jika materi 
bahasa Arab diberikan terlalu rendah atau mudah, maka mahasiswa yang berasal dari pondok pesantren akan merasa jenuh dan cepat bosan mengikuti pembelajaran karena sudah pernah mereka dapatkan materi itu sebelumnya. Sementara mengajar dalam lingkungan formal harus berdasarkan kurikulum dan silabus yang diterapkan pada saat pembelajaran dilaksanakan. Ini merupakan PR tersendiri bagi dosen yang mengampu mata kuliah bahasa Arab di Jurusan non pendidikan bahasa Arab termasuk di dalamnya Jurusan PGMI.

Hasil wawancara peneliti dengan dosen pengampu mata kuliah bahasa Arab di PGMI peneliti mendapatkan data bahwa, dalam pelaksanaan pembelajaran bahasa Arab dosen tetap mengacu pada kurikulum yang diterapkan di fakultas Tarbiyah Ilmu Keguruan khususnya Jurusan PGMI, namun untuk materi ajarnya yang akan disampaikan ke mahasiswa disesuaikan dengan taraf kemampuan sebagian besar mahasiswa. Untuk mengetahui taraf kemampuan mahasiswa sebelum memulai pembelajaran bahasa Arab dosen terlebih dahulu melakukan apersepsi untuk menjajaki sejauh mana tingkat pemahaman mahasiswa dalam belajar bahasa Arab.

Menurut dosen pengampu bahasa Arab ini juga sebagian besar dari mahasiswa bisa mengikuti perkuliahan dan bisa menjawab pertanyaan yang dosen ajukan jika cara menjawabnya secara bersama-sama, namun jika mereka diberi pertanyaan secara individual akan kesulitan dalam menjawabnya. Hal ini tentunya membuat dosen pengampu menjadi tertantang menggunakan metode lain yang bisa membuat mahasiswa dapat menjawab pertanyaan yang diajukan dosen baik secara individu maupun kelompok.

Dosen harus lebih telaten dalam menjelaskan materi yang akan disampaikan. Materi yang sudah disampaikan tidak jarang harus diulang kembali pada pertemuan berikutnya supaya mahasiswa benar-benar memahami materi yang disampaikan. Seperti halnya penjelasan mengenai qawaid yang terkandung dalam teks yang diberikan, maka dosen harus kembali menjelaskan ulang apa yang di maksud dengan mudhof dan mudhof ilaih, apa yang dimaksud dengan na'at man'ut, apa yang dimaksud jar majrur dan fungsinya. Pemahaman akan qawaid yang benar menentukan ketepatan bacaan teks yang diberikan. Maka kesabaran dosen sangat diperlukan dalam pembelajaran ini.

Begitu juga dalam menjelaskan sharaf, dosen harus sangat sabar dalam menjelaskan nya. Karena ketepatan pemahaman mahasiswa akan menentukan ketepatan mahasiswa dalam memberikan harakat akhir dalam suatu tulisan Arab.

\section{Hambatan Mahasiswa dalam Pembelajaran Bahasa Arab}

Mahasiswa lulusan sekolah umum sama sekali belum mengenal bahasa Arab di sekolahnya, mereka kesulitan dalam mempelajari bahasa Arab di bangku perkuliahan, mereka juga merasa kesulitan dalam mempelajari qawaid/saraf, sedikit perbendaharaan mufradat, sulit dalam menterjemahkan 
kalimat-kalimat Arab. Belum memiliki kamus Arab sehingga belum terbiasa menggunakan kamus Arab dalam pembelajaran.

Sedangkan hambatan-hambatan yang dialami mahasiswa lulusan dari Sekolah berbasis Agama baik negeri maupun swasta atau Sekolah Kejuruan Swasta yang sudah mempelajari bahasa Arab di sekolahnya yaitu Mahasiswa masih menemukan kosakata asing yang belum pernah dipelajari sebelumnya, kurang menguasai qawaid, belum lancar dalam menyusun kalimat Arab, belum memahami bentuk jumlah ismiyyah dan jumlah fi'liyyah, belum memahami susunan na'at man'ut, mudhaf mudhaf ilaih, masih kesulitan dalam menerjemahkan kalimat-kalimat Arab, merasa sulit dalam menerjemahkan kalimat Arab dan menyusun kalimat-kalimat Arab, namun sebagian besar mereka sudah memiliki kamus Arab.

Lebih lanjut, hambatan-hambatan yang ditemui mahasiswa PGMI lulusan atau sedang belajar di pondok pesantren yaitu Mahasiswa tidak memiliki banyak kendala yang berarti dalam mempelajari bahasa Arab tapi terkadang masih menemukan kosakata baru, sedikit kesulitan dalam mempelajari qawaid tapi termudahkan dengan pelajaran bahasa Arab yang mereka dapat di pondok pesantren, serta mahasiswa sudah lancar menggunakan kamus berbahasa Arab, mahasiswa yang tinggal di pondok pesantren salaf lebih mempelajari ilmu alat/ nahwu sharaf dan tidak diwajibkan percakapan bahasa Arab sehingga mereka kesulitan dalam percakapan berbahasa Arab,sedangkan mahasiswa yang tinggal di pondok pesantren modern lebih ditekankan pada penerapan komunikasi berbahasa Arab sehari-hari tetapi kurang dalam pembelajaran ilmu nahwu dan ilmu sharaf.

Dari beberapa hambatan dan kesulitan yang dialami mahasiswa dalam pembelajaran bahasa Arab tersebut, peneliti mendapatkan solusi agar pembelajaran bahasa Arab mudah diterima oleh mahasiswa PGMI.

a. Sebaiknya dalam pemberian materi pelajaran bahasa Arab hendaknya diamati dulu tingkat kemampuan mahasiswa dalam pemahaman bahasa Arab.

b. Sebaiknya pada data asal lulusan sekolah sebelum memulai materi untuk mempermudah pemberian materi yang tepat kepada mahasiswa.

c. Sebaiknya gunakan buku pelajaran bahasa Arab berbahasa Indonesia agar mahasiswa lebih mudah memahami materi bahasa Arab.

d. Membiasakan mahasiswa menggunakan kamus bahasa Arab dalam proses pembelajaran.

e. Memberikan tugas setoran hafalan mufrodat di awal pelajaran.

f. Berikan variasi mengajar dengan permainan-permainan bahasa agar pembelajaran lebih menyenangkan.

g. Berikan pemahaman secara jelas tentang perbedaan isim, fiil. 
h. Berikan pemahaman yang jelas tentang jumlah ismiyyah dan jumlah fi'liyyah.

i. Jangan memberikan teks wacana yang banyak menggunakan bahasa yang sulit difahami.

j. Dalam pembelajaran sambil digunakan percakapan dengan bahasa Arab secara sederhana agar mahasiswa terbiasa berkomunikasi bahasa Arab.

k. Senantiasa melakukan review materi pelajaran.

1. Memberi kesempatan mahasiswa bertanya.

m. Membiasakan mahasiswa selalu menjawab pertanyaan berbahasa Arab.

n. Menunjuk beberapa mahasiswa yang memiliki pemahaman yang lebih baik untuk membantu memberikan penjelasan kepada temannya yang masih kesulitan dalam pembelajaran.

o. Buat suasana pembelajaran yang rileks dan tidak menegangkan.

p. Bangun suasana keakraban dengan mahasiswa sehingga mahasiswa tidak merasa takut atau enggan belajar bahasa Arab.

q. Selalu bangun opini mahasiswa bahwa pembelajaran bahasa Arab itu mudah dan menyenangkan.

\section{Analisa Penelitian}

Mempelajari bahasa Arab memerlukan waktu yang cukup lama dan terus-menerus. Sangat penting pengenalan bahasa Arab dari pendidikan tingkat dasar hingga perguruan tinggi karena dengan mempelajari bahasa Arab berarti juga mempelajari bahasa Al-Quran. Pengenalan bahasa Arab sedari kecil akan mempermudah individu dalam mempelajari bahasa Arab di jenjang pendidikan selanjutnya. Pengenalan yang terlambat akan menyulitkan mahasiswa belajar bahasa Arab di perguruan tinggi.

Ragam pemahaman di sini adalah perbedaan tingkat pemahaman mahasiswa PGMI berdasarkan lulusan Sekolah Menengah Atas yang pernah mereka tempuh. Bahwa mahasiswa lulusan sekolah umum belum mendapatkan pelajaran bahasa Arab sehingga mereka menemui kesulitan dalam belajar bahasa Arab di bangku perkuliahan Jurusan PGMI. Hendaknya mereka harus intensif dalam pembelajaran bahasa Arab dan menambah waktu belajar di luar perkuliahan dengan menambah jam belajar di tempat kursus atau pondok pesantren.

Namun mahasiswa yang berasal dari lulusan sekolah menengah swasta sudah mendapatkan pelajaran bahasa Arab namun masih terkendala dengan pengenalan mufradat baru sehingga sebaiknya mereka harus banyak membuka kamus bahasa Arab dan menghafalkan setiap mufradat/ kosakata yang mereka dapatkan di bangku perkuliahan. Mereka sudah ada yang mempelajari bahasa Arab. Sama halnya dengan Sekolah Menengah umum Swasta yang biasanya dimiliki oleh organisasi keagamaan seperti Muhammadiyah dan NU. Namun jam pelajarannya terbatas dalam satu minggunya. 
Mahasiswa yang tinggal di pondok pesantren salaf sebaiknya membiasakan diri berkomunikasi dengan bahasa Arab di keseharian mereka di pesantren dana mahasiswa yang tinggal di pondok pesantren modern sebaiknya lebih tekun lagi dalam belajar ilmu alat atau nahwu dan shorofnya.

Bahasa Arab bukan bahasa yang sulit dipelajari. Bahasa Arab adalah bahasa modern sepanjang zaman sehingga belajar bahasa Arab adalah hal yang modern. Bahasa Arab tidak sulit dipelajari asalkan dengan metode yang tepat mempelajarinya.

Mengajarkan bahasa Arab bagi guru bahasa Arab adalah hal yang unik dan menarik. Mengajarkan bahasa Arab memerlukan kesabaran dan keseriusan dalam menyampaikannya. Buku-buku yang digunakan dalam pembelajaran bahasa Arab sebaiknya dicari yang mudah dipahami anak didik. Jangan gunakan kitab yang semuanya berbahasa Arab jika basis pendidikan anak didiknya beragam. Suasana yang menyenangkan selama proses pembelajaran adalah hal yang wajib diwujudkan oleh dosen dalam kegiatan pembelajaran bahasa Arab, agar tercapai tujuan pembelajaran ketika proses pembelajaran bahasa Arab di jurusan PGMI sudah selesai dilaksanakan.

\section{E. Simpulan}

Ragam pemahaman bahasa Arab adalah perbedaan tingkat pemahaman mahasiswa PGMI dalam mempelajari bahasa Arab berdasarkan asal lulusan Sekolah Menengah Atas yang pernah mahasiswa tempuh. Mahasiswa yang berasal dari Sekolah Menengah Atas Negeri belum pernah mempelajari bahasa Arab. mahasiswa yang berasal dari lulusan Sekolah Menengah Atas Swasta ada yang sudah mempelajari bahasa Arab. Mahasiswa yang berasal dari Sekolah berbasis agama baik negeri maupun swasta sudah pernah mempelajari bahasa Arab. Mahasiswa yang berasal dari pondok pesantren sudah sangat mengenal tentang bahasa Arab beserta keempat maharah/ skill dalam pelajaran bahasa Arab. Kesulitan-kesulitan yang ditemui mahasiswa dalam pembelajaran bahasa Arab diantaranya karena belum pernah mempelajari bahasa Arab sebelumnya, mendapatkan kosakata baru yang masih asing bagi mereka sehingga mereka sulit dalam menyimak maupun menghafalkan kosakata, kesulitan dalam penyusunan kalimat berbahasa Arab. Pemahaman mahasiswa tentang ilmu alat (nahwu dan sharaf) sangat diperlukan. Proses memahami ilmu alat memang membutuhkan waktu yang cukup panjang dan terus menerus dalam mempelajarinya. Hal ini tentu tidak akan cukup waktu jika hanya mengandalkan belajar bahasa Arab di dalam kelas saja. Maka mahasiswa harus mempunyai inisiatif sendiri untuk belajar bahasa Arab di luar kelas. Kesulitan-kesulitan mahasiswa akan bisa diatasi jika mahasiswa mempunyai kemauan yang tinggi dalam belajar bahasa Arab dimana pun ia bisa mendapatkan kesempatan untuk mempelajarinya. 


\section{Daftar Pustaka}

Ainin, Moh. Metodologi Penelitian Bahasa Arab. Malang: Hilal Pustaka, 2007.

Arsyad, Azhar. Bahasa Arab dan Metode Pengajarannya. Yogyakarta: Pustaka Belajar, 2003.

Kamus Besar Bahasa Indonesia (KBBI) Online. “Arti Kata Paham.” Diakses 10 Oktober 2019. https://kbbi.web.id/paham.

Kamus Besar Bahasa Indonesia (KBBI) Online. "Arti Kata Ragam.” Diakses 9 Oktober 2019. https://kbbi.web.id/ragam.

Aunurrahman. Belajar dan Pembelajaran. Bandung: Alfabeta, 2009. Hermawan, Acep. Metodologi Pembelajaran Bahasa Arab. Bandung:

Remaja Rosdakarya, 2014.

Khalilullah, M. Media Pembelajaran Bahasa Arab. Yogyakarta: Aswaja Pressindo, 2012.

Mawardi. Dasar-Dasar Pembelajaran Bahasa Arab. Sulawesi Selatan:

Laskar Perubahan, 2015.

Moleong, Lexy J. Metodologi Penelitian Kualitatif. Bandung: Remaja Rosdakarya, 2012.

Mu'in, Abdul. Analisis Kontrastif Bahasa Arab dan Bahasa Indonesia:

Telaah terhadap Fonetik dan Morfologi. Jakarta: Pustaka Al Husna

Baru, 2004.

Rahmi, Novita. "Problematika Penerapan Sistem Nazhariyyah Al Wahdah Pada Pembelajaran Bahasa Arab Di Madrasah Aliyah Se-Kota Metro Tahun 2018." An Nabighoh: Jurnal Pendidikan Dan Pembelajaran Bahasa Arab 21, no. 01 (2019): 61-76. https://doi.org/10.32332/annabighoh.v21i01.1253.

Ridjaluddin F. N., dan Anang Rohwiyono. Bunga Rampai Pendidikan Islam. Jakarta: Pusat Kajian Islam FAI UHAMKA, 2008.

Sanjaya, Wina. Strategi Pembelajaran. Jakarta: Kencana Prenada Media Group, 2006.

Sugiyono. Metodologi Penelitian Administrasi. Bandung: Alfabeta, 1999.

Suja'i. Inovasi Pembelajaran Bahasa Arab. Semarang: Walisongo Press, 2008.

Sukamto, Imaduddin, dan Akhmad Munawari. Tata Bahasa Arab Sistematis:

Pendekatan Baru Mempelajari Tata Bahasa Arab. Yogyakarta:

Nurma Media Idea, 2007.

Suprihatiningrum, Jamil. Strategi Pembelajaran Teori dan Aplikasi.

Yogyakarta: Ar-Ruzz Media, 2013.

Thoifah, I'anatut. Statistika Pendidikan dan Metode Penelitian Kuantitatif.

Malang: Madani, 2006. 